$1 \mathrm{P} 055$

\section{タンパク質の構造・安定性に及ぼす環状オリゴ糖およびポリ オールの添加効果}

Effects of polyol and cyclic oligosaccharide on structure and stability of protein

Takayuki Iokibe, Dai Katou, Takuya Hamada, Takayoshi Kimura (Fac. Science, Kinki Univ.)

Polyol and cyclic oligosaccharide (cyclodextrin, CD) influence structure and stability of protein through hydrophobic interaction. We have determined thermodynamic properties of molten globule (MG) state of cytochrome $\mathrm{c}$ induced by polyol and unfolded state by temperature with CD. In this study, to reveal the thermodynamic properties of MG state of myoglobin, thermal denaturation of myoglobin in aqueous sorbitol solution were measured by circular dichroism and DSC. Sorbitol induced the MG state from acid unfolded state at $\mathrm{pH} 2,290 \mathrm{~K}$, and over $3 \mathrm{M}$ of sorbitol, and the MG state was unfolded by increasing temperature with low cooperativity. The kinetic properties of MG state was determined by stopped flow measurement.
1P058

バクテリア細胞質の全原子分子動カ学シミュレーション

All-Atom Molecular Dynamics Simulation of Bacterial

Cytoplasm

Isseki Yu ${ }^{1,2}$, Takaharu Mori ${ }^{1}$, Jaewoon Jung ${ }^{2}$, Ryuhei Harada ${ }^{2}$, Yuji Sugita ${ }^{1,2}$, Michael Feig ${ }^{3}$ ( ${ }^{1}$ RIKEN Advanced Science Institute, ${ }^{2}$ RIKEN Advanced Institute for Computational Science, ${ }^{3}$ Michigan State University)

Computer simulation of the realistic cellular environment is one of the major challenges for biophysical scientists. It is indispensable in obtaining the molecular-level dynamic picture of the biochemical reaction networks. For this purpose, we constructed all-atom model of cytoplasm in the Mycoplasma genetalium, the smallest bacteria. The size of the system is $50 \times 50 \times 50 \mathrm{~nm}$, which is greatly exceeds that of typical MD simulations, covering about $1 \%$ of the volume of an entire cell. Using the trajectories generated by highly parallelized MD program GENESIS on K computer, the dynamics of the macromolecules/metabolites are analyzed. The correlation between MD-derived spatiotemporal data with experimentally known biochemical reaction networks is also discussed.

\section{$1 \mathrm{P} 056$ タンパク質の熱安定性に及ぼすシクロデキストリンの包接 効果}

Inclusion effects of cyclodextrin on thermal stability of proteins

Toshiki Miki, Takayuki Iokibe, Takayoshi Kimura, Tadashi Kamiyama (Fac. Science Kinki Univ.)

The protein structure is maintained by a significant small stability as a compensated result of hydrophobic interaction, hydrogen bond, electrostatic interaction, structural entropy, and other enthalpic and entropic factors. Cyclodextrins (CDs) can influence the conformation and stability of protein via their inclusion ability. In this study, thermal denaturations of several globular proteins in aqueous CD solutions were measured by DSC. CD concentration dependence of midpoint temperature and change in enthalpy for thermal denaturation of proteins indicate the $\mathrm{CD}$ destabilized the folded state of proteins by stabilizing the unfolded state due to inclusion. The effect was dependent on the property of proteins.

\section{$1 \mathrm{P} 057$ \\ 粗視化シミュレーションを用いた STMV の自己組織化につ いての理論的研究}

Theoretical study on the self-assembly of satellite tobacco mosaic virus using coarse grained simulation

Masato Teranishi, Micke Rusmerryani, Kazutomo Kawaguchi, Hiroaki Saito, Hidemi Nagao (Grad. Sch. Nat. Sci., Univ. Kanazawa)

Satellite tobacco mosaic virus (STMV) is composed of 60 identical copies of a single protein with an icosahedral structure. In this work, we investigate the assembly mechanism of the STMV particle by simulations with Go like model, which is a kind of coarse grained model. For the purpose of understanding the assembly mechanism of a virus particle, it is significant to study interactions both intra- and inter-subunits of capsid proteins because the interactions highly contribute to the structural stability of a whole virus particle. Electrostatic, Van der Waals, hydrophobic and hydrogen bonding interactions are applied to protein-protein interactions. We then discuss the stability and which interaction is dominant for completing the assembly of the STMV particle.
$1 \mathrm{P059}$

\section{分子動カ学シミュレーションによる構造エントロピー計算法 の比較}

Comparison of calculation methods of configurational entropy from molecular dynamics simulation trajectories

Simon Hikiri ${ }^{1}$, Takashi Yoshidome ${ }^{2}$, Mitsunori Ikeguchi ${ }^{1,2}\left({ }^{1}\right.$ Grad. Sch. of Nanobioscience, Yokohama City Univ., ${ }^{2}$ Grad. Sch. of Med. Life Sci., Yokohama City Univ.)

Configurational entropy $\left(\mathrm{S}^{\mathrm{c}}\right)$ is one of important properties in many biomolecular processes such as molecular binding. So far, many methods to calculate $S^{c}$ from trajectories of the molecular dynamics simulations have been proposed. Recently, Harpole and Sharp proposed the Clausius method which enables us to exactly calculate the temperature difference in $\mathrm{S}^{\mathrm{c}}$ without any approximations such as quasi-harmonic distributions. ${ }^{[1]}$ In this study, we compared results of the Clausius method with those of several methods for entropy calculation, including quasi-harmonic methods based on principal component analysis using Cartesian coordinates. [1] K. W. Harpole and K. A. Sharp, J. Phys. Chem. B, 115, 9461(2011).

$1 \mathrm{P} 060$

\section{分子モデリング法を用いた酸変性アポミオグロビンの構造 解析}

A Conformational Analysis of Acid Unfolded Apomyoglobin using a Novel Molecular Modeling Method

Yasutaka Seki ${ }^{1}$, Takamasa Nonaka ${ }^{1}$, Kunitsugu Soda ${ }^{2}\left({ }^{1}\right.$ Sch. of Pharm., Iwate Med. Univ., ${ }^{2}$ High Perform. Molec. Simula. Team, ASI, RIKEN)

The unfolded protein in solution consists of an ensemble with a great number of conformations. It is necessary to integrate diverse experimental data for elucidating its structural properties. We developed a new computational method for generating conformations of unfolded protein (Seki, Y. et al., JCTC, 2011). Using our method, we have tried to find an ensemble which best reproduces experimental data obtained from both residual dipolar couplings of NMR and solution X-ray scattering. As a result, it was clarified that structural properties of the acid-unfolded (AU) apomyoglobin. In the annual meeting, we will discuss differences in structural properties between urea unfolded state and AU state. 